\title{
„Po śmierci próżniaka nie zawyje i sobaka": образ ледаря та трудолюба в зоофразеології (на матеріалі польської, української та російської мов)
}

\begin{abstract}
Myroshnichenko Ilona, „Po śmierci próżniaka nie zawyje i sobaka”: obraz ledarya ta trudolyuba v zoofrazeologii (na materiali pol's'koí, ukrains'koi ta rosijs 'koi mov) ("Po śmierci próżniaka nie zawyje i sobaka": the Image of a Lazy Person and a Hard Worker in Zoophraseology [Based on Polish, Ukrainian and Russian Languages]). "Poznańskie Studia Slawistyczne" 20. Poznań 2021. Publishing House of the Poznań Society for the Advancement of the Arts and Sciences, Adam Mickiewicz University, pp. 51-69. ISSN 2084-3011.

The article analyzes the zoophraseologisms to denote a lazy and a hard worker. It was found that the images of a bee, a horse (in all studied languages), a donkey (the Ukrainian language), a bull, a louse (the Russian language), and an ant (the Polish language) were used in the phraseology for a positive description of person. Laziness and idleness in phraseology personify the images of a cat (in all studied languages), a bird, a louse (Polish and Ukrainian languages), a drone (Ukrainian and Russian languages), a donkey (the Russian language), a dog, a hen (the Ukrainian language). Ambivalent connotations in phraseology have images of an ox (in all studied languages), a dog (Polish and Russian languages), a hen, a donkey (the Polish language). Negatively colored phraseologies prevail over positively ones. In most cases, the semantics of phraseology is related to the way of life of animals, which people perceive it, to a lesser extent - the plots of fairy tales, pagan traditions, culinary and hunting practices. Decoding of some phraseologies is complicated by the homonymy of animal names.
\end{abstract}

KEYWORDS: zoophraseology; zoophraseologism; image; animal; connotation; motivation

Фразеологізми, до складу яких входять назви тварин, викликають значний науковий інтерес у слов'янському мовознавстві. Так, Юлія Ігорівна Сагата (2013) досліджувала динамічні процеси в сучасній польській фразеології з анімалістичним компонентом на матеріалі текстів, вилучених з Національного корпусу польської мови, 
інтернет-текстів і даних анкетних досліджень. Науковчиня виявила поширені прийоми модифікації традиційних структури та значення фразеологічних одиниць і здійснила детальний аналіз механізмів їх реалізації. Вивченню структури, семантики та внутрішньої форми польських фразеологізмів із зоонімами присвячено дисертацію Марії Вікторівни Пасюрківської (2009б). Дослідниця встановила виникнення супровідних оцінних конотацій, простежила, з якими морально-етичними категоріями співвідносяться назви відповідних тварин. Досліджено роль та властивості зоосемічних компонентів й партонімічних одиниць при фразеотворенні, особливості вираження їх семантики, а також вироблено класифікацію анімалістичних концептів, удосконалено типологію зоофразеологізмів та поняття зоофразеологічної одиниці в дисертаційному дослідженні Алли Василівни Гребенюк (2014). Виявлено активні структурно-семантичні моделі у східнослобожанських і степових говірках Донбасу, досліджено характер віддзеркалення українськими зоофразеологізмами позамовної дійсності у зв'язку з їх формуванням, еволюцією та здатністю до культурної референції (Ужченко, 2000). Ірина Кононенко у монографії Украӥнська та польська мови: контрастивне дослідження торкнулася питання відмінностей українського та польського світосприймання, втілених у зоофразеології (Кононенко, 2012, 294, 311-312). Досліджуючи семантику польських зоофразеологізмів семантичного поля „працьовитість / неробство” я помітила значну подібність польської фразеології з аналогічною фразеотематичною групою української та російської мов (детальніше v. Мирошніченко, 2011; 2014). Подібні зіставлення становлять чималий науковий інтерес у плані встановлення типологічних паралелей та мовних універсалій, що спонукало мене продовжити дослідження, розширивши добірку фразеологічного матеріалу, долучивши діалектні і літературні фразеологізми української та російської мов.

Науковці по-різному називають фразеологізми, до складу яких входять назви тварин: фразеологічні одиниці з анімалістичним компонентом (Сагата, 2013, 1; Пасюрківська, 2009a, 3; Rak, 2007a, 6), анімалістичні фразеологічні одиниці (Бирюкова, 1990, 3) фразеологізми із зоонімами (Пасюрківська, 2009а, 14), фразеологізми з зоосемічним компонентом (Гребенюк, 2014, 1) зоофразеологізми (Ужченко, 2000, 
16; Гребенюк, 2014, 2; Пасюрківська 2009a, 3). Погоджуюсь 3 думкою Дмитра Вікторовича Ужченка, що найбільш універсальним $i$ коректним $\epsilon$ термін зоофразеологізм (Ужченко, 2000, 1). Тож у статті фразеологізми, до складу яких входять назви тварин, називатиму зоофразеологізмами.

3 огляду на те, що в науковій літературі на позначення прислів'їв, приказок, приповідок та афористичних висловів уже давно функціонує термін паремії, а їх вивченням займається окрема галузь на межі мовознавства й фольклористики - пареміологія, у пропонованому дослідженні приймаю вузьке розуміння фразеології. Під зоофразеологізмом розумію семантично неподільні, відтворювані, відносно стійкі образні вислови, у структурі яких головним або залежним компонентом виступає лексема, що є назвою тварини.

У статті проаналізовано 123 зоофразеологізми - 43 польської, 52 української та 28 російської мови, зібрані методом суцільної вибірки 3 фразеологічних, діалектних лексикографічних праць досліджуваних мов.

Мета цієї розвідки дослідити особливості формування образу ледаря та трудолюба в польській, українській та російській зоофразеології. Досягнення поставленої мети передбачає розв'язання таких завдань: визначити, які образи тварин, комах та птахів використовуються у фразеології для характеристики працьовитої людини, яка сумлінно ставиться до роботи, багато і важко працює, а які - уособлюють лінь та неробство; з'ясувати, які образи тварин викликають у носіїв досліджуваних мов спільні конотації, а які - відмінні; розкрити внутрішню форму зоофразеологізмів, простежити зв'язок з етнокультурними факторами.

Зоофразеологія належить до одного $з$ найчисленніших та найдавніших пластів фразеології чи не кожної мови. Досліджуюючи мовну концептуалізацію тваринного світу в українській фразеології, Олена Олександрівна Селіванова зауважує, що „тваринний світ завжди був водночас близьким і загадковим для людини, вона збагачувала спектр найменувань ознак, якостей, дій, станів за рахунок знакових ресурсів тваринного світу з огляду на свої уявлення, його оцінки, стереотипи цього світу" (Селіванова, 2004, 145).

Досліджуюючи мовно-культурний образ тварин, зафіксований у польській діалектній анімалістичній фразеології, Матвій Рак (Rak, 
2007а) констатує, що найчисельнішою є група фразеологізмів, що містить назви домашніх улюбленців. За підрахунками науковця близько 150 фразеологізмів і варіантів стосуються собаки, а 100 - кота.

Мовний образ кота неодноразово розглядався в польському та українському мовознавстві. Цій темі, зокрема на матеріалі польської мови, присвячені розвідки Януша Анусевича (Anusiewicz, 1990) та Катерини Мосьолек-Клосіньської (Mosiołek-Kłosińska, 1995). На матеріалі української діалектної фразеології образ кота вивчали Галина Миронівна Доброльожа (2005), Наталія Олександрівна Олексієнко (2008). Семантику українських та польських фразеологізмів 3 компонентом кim - kot 3 точки зору виокремлення конотацій, пов'язаних із цим словом у свідомості поляків та українців, аналізувала Сагата (2008). Проте, якщо на матеріалі української мови докладно розглянуто такі стереотипні риси характеру кота, як лінь та ледарство, то на матеріалі польської мови їм не приділено належної уваги.

Образ кота в носіїв польської, російської та української мов викликає негативні конотації. Прикметно, що саме негативні риси характеру цієї тварини відтворює українська народна загадка: I в день і в ночі у кожусі на печі (Жайворонок, 2018, 306). Корисна діяльність домашнього улюбленця - знищувати мишей та щурів, на жаль, не відбилася у фразеології, зате бажання поманіжитися на сонечку чи поспати у холодочку, а іншими словами, дармоїдство та ледарство, фіксуємо у ряді фразеологізмів досліджуваних мов: пор. пол. spracowat sie jak kot w popiele (na piecu) (Wysoczański, 2006, 163), leniwy jak [stary] kot (Rak, 2007a, 115), pracowity jak kot na piecu (Adalberg, 1894, 431); укр. заліг як кошеня в грубі (Доброльожа, 2003, 26), розлігся як кіт на печі (Доброльожа, 2003, 29), лінивий як [жирний] кіт (Доброльожа, 2003, 27), ледачий як кіт у жнива (Доброльожа, 2003, 27), лінива як кішка на печі (Мацюк, 2013, 437), лінивий як сто котів укупі (Мацюк, 2013, 437), ледачий як котюра (Доброльожа, 2003, 27), ледачий як старий кіт: тільки наїсться i спить (Доброльожа, 2003, 27), наробить як кіт на глині (Мацюк, 2013, 438), вивернувся як кіт на припічку (Ужченко, Ужченко 2013, 254), лежить як кіт у запічку (Юрченко, Івченко, 1993, 68), працүює як кіт на печі (Юрченко, Івченко, 1993, 69); рос. лежать (валяться) как кот на печи (Мокиенко, Никитина, 2008, 298). 
На відміну від кота, образ собаки у польській та російській фразеології використовується не лише для характеристики лінивої людини (пор. пол. tak тu się chce pracować jak, psu orać (Wysoczański, 2006, 155), taki do roboty, jak pies do galasu (Wysoczański, 2006, 155), chce się mu robić, jak psu kija grzyźć (Reichan, Urbańczyk, 1991, 479), chce się mu robić, jak zdechłemu psu szczekać (Reichan, Urbańczyk, 1991, 479); рос. бегает от работы как собака от мух (Мокиенко, Никитина, 2008, 629), ленивый как собака (Мокиенко, Никитина, 2008, 631), але й працьовитої (пор. пол. pracować [harować] jak pies; Wysoczański, 2006, 154); рос. работать как собака [в лесу] „важко, виснажливо працювати" (Мокиенко, Никитина, 2008, 633), загнать кого как собаку в колесо „про людину, яка змушена виконувати важку роботу” (Мокиенко, Никитина, 2008, 633). В українській фразеології образ собаки, як і образ попереднього домашнього улюбленця, негативно конотований: до роботи як собака до солі (Доброльожа, 2003, 26), моторний як собака чорний (Доброльожа, 2003, 28), ледачий як пес чорний (Доброльожа, 2003, 28), ховається від роботи як собака від мух (Доброльожа, 2003, 29), хоче робити як собака орати (Доброльожа, 2003, 30), гнилий як пес (Юрченко, Івченко, 1993, 113), боїться роботи як собака мух (Юрченко, Івченко, 1993, 141), заліг як собака в грубі (в солому) (Юрченко, Івченко, 1993, 141), лежить як пес на стерні (Юрченко, Івченко, 1993, 114), хочеться робити як старому псові в завірюху брехати (Юрченко, Івченко, 1993, 114), лінивий як пес (Мацюк, 2013, 473), працъює як собака уві сні (Доброльожа, 2004, 225).

Селіванова $(2004,151)$ негативні конотації собаки пояснює стереотипізацією у фразеологізмах чужого собаки, що охороняє чийсь будинок, не підпускаючи сторонніх.

Образ вола в польській, українській та російській фразеології має амбівалентні конотації. 3 одного боку, його образ використовується для характеристики лінивої людини, яка ухиляється від роботи: пор. пол. leniwy jak wót (Krzyżanowski, 1970, 292), укр. лінивий як віл (Юрченко, Івченко, 1993, 25), рос. вертеть вола [за хвост] „ледарювати" (Мокиенко, Никитина, 2007, 97; Бирих, Мокиенко, Степанова, 1998, 94), з другого - для характеристики працьовитої людини, яка сумлінно ставиться до роботи, багато і важко працює: пор. пол. pracować (harować, tyrać, orać, zasuwać) jak [ten] wót [roboczy] 
(Kłosińska, Sobol, Stankiewicz, 2005, 629; Müldner-Nieckowski, 2004, 889), wół roboczy (Kłosińska, Sobol, Stankiewicz, 2005, 629), pracowity jak wól (wołek) (Krzyżanowski, 1970, 1058); укр. пахати як віл (Мацюк, 2013, 433), наробитися як віл (Мацюк, 2013, 433, 434); рос. трудолюбивый как вол (Мокиенко, Никитина, 2008, 108), работать (nахать, трудиться, горбачить, ломить, шухлить) как [бурыий, серый] вол (Мокиенко, Никитина, 2008, 89, 108, 109, 110). У російській мові фіксуємо фразеологізми, де образ вола замінено образом бика: пор. укр. працює (гарує) як [чорний] віл [у ярмі] (Юрченко, Івченко, 1993, 24, 25), рос. работать как бык в ярме (Мокиенко, Никитина, 2008, 77); укр. тягнути як віл (Мацюк, 2013, 435), рос. везти (тянуть) как бык (Мокиенко, Никитина, 2008, 76). Приклади, які говорять про ледачість вола, М. Рак мотивує не стільки небажанням тварини працювати, скільки іiі повільністю: „Z perspektywy człowieka ten, kto jest powolny, jest bowiem uznawany za leniwego" (Rak, 2007b, 78).

Суперечливі конотації викликає образ віслюка (мула) лише в носіїв польської мови: leniwy jak osioł (mut) „ледар, дармоїд” (Krzyżanowski, 1970, 291), oblekać się w ośla skórę „байдикувати” (Skorupka, 1967, 531), pracować (harować, tyrać, orać, zasuwać) jak [dziki] osiot „важко, виснажливо працювати" (Müldner-Nieckowski, 2004, 500), chodzić jak [osiot, muł] w kieracie „важко, виснажливо працювати” (Müldner-Nieckowski, 2004, 298), ośli trud (zajęcie, praca) „важка, виснажлива робота" (Skorupka, 1967, 626). Натомість у російській фразеології образ цієї свійської робочої тварини викликає лише негативні конотації: ленивый как осёл „ледар, дармоїд” (Мокиенко, Никитина, $2008,468)$. Владислав Копалінський припускає, що негативний образ віслюка сформувався на основі байок (осел виступає в 30 байках Езопа), де йому приписують неробство та обжерливість. Хоча насправді, як зазначає автор, „важко знайти тварину працьовитішу і менш перебірливу" (Кopaliński, 2003, 893). В українській західноподільській діалектній фразеології образ ішака (розмовна назва віслюка) використовується для характеристики працьовитого чоловіка, який багато і важко працює: пахати як ішак (Мацюк, 2013, 433).

Спільні конотації має образ коня в польській, російській та українській фразеології. Образ свійської тварини використовується для характеристики людини, яка багато і важко працює: пор. пол. 
pracować (harować, tyrać, orać, zasuwać) jak koń (szkapa) (Kłosińska, Sobol, Stankiewicz, 2005, 629; Krzyżanowski, 1970, 1056), chodzić jak [koń] w kieracie (Müldner-Nieckowski, 2004, 298), koń roboczy (Müldner-Nieckowski, 2004, 319), koń dyszłowy (pociagłowy) (Müldner-Nieckowski, 2004, 319); рос. езжалая лошадь (Мокиенко, Никитина, 2007, 371), работать (вкальвать, пахать, ломить, ищачить) как [ломовая, загнаная] лошадь (лошадюга) [Пржевальского] (Мокиенко, Никитина, 2008, 358); укр. гарувати (працювати, пахати) як кінь [у кираті] (Юрченко, Івченко, 1993, 25, 66, 67; Мацюк, 2013, 433), кінь гариований (Доброльожа, 2010, 239), роботяща як коняка (Мацюк, 2013, 434).

Неспроможність виконання примітивної роботи, що не вимагає попередньої фахової підготовки, а отже, під силу будь-якій людині, покладена в основу пол. фразеологізму nie umieć i kozie ogona zawiazać „про людину, яка не здатна виконувати найпростішу роботу” (Skorupka, 1968, 789). Ю. Кшижановський припускає, що цей зворот пов'язаний з давньою поганською традицією - в останні дні карнавалу (пол. zapusty) ходити по хатах $з$ козою (Krzyżanowski, 1960, 141). У Польщі в останній вівторок карнавалу (пол. podkoziołek) молодь влаштовувала в корчмі забави. Особливість цих гулянь полягала в тому, що забаву оплачували дівчата. Бочку з трунком накривали білим полотном, а зверху бочки на тарілочці ставили дерев'яну фігурку козла або хлопчика з рогами, що мала символізувати тварину. Цей звичай подекуди зберігся до сьогодні у Великопольщі та на Помор'ї. За переказами старожилів, звичай мав забезпечити урожайність льону та коноплі, які були основним матеріалом для жіночих робіт (Kopaliński, 2003, 991-992). Фігурка козла була не лише атрибутом свята, але й мала символічне значення: козел експонував чоловічі риси, плодовитість, здатність розмножуватися. За старопольською традицією, підкозликом (пол. podkoziołek) називали гру, у якій висміювали парубоцтво. У цей день знущалися над неодруженими хлопцями та дівчатами. Часто до їхнього одягу пришпилювали різні непристойні речі. Можливо, серед цих непристойностей і був хвіст козла, що мав своє символічне значення. Окрім того, влаштовували своєрідні „,аукціони” наречених, де можна було „придбати” майбутню дружину. Можна припустити, що фразеологізм nie umieć i kozie ogona zawiązać виник 
на основі давньої традиції зав'язувати коневі у дощовий період хвіст, де образ коня, щоб надати фразеологізму комічного забарвлення, замінений на образ козла. Як зазначає Ю. Кшижановський, коневі зав’язували хвіст, щоб оберегти цінне волосся тварин від болота. А оскільки хвіст у коня був довгий, то зробити це не викликало великих труднощів (Krzyżanowski, 1960, 140). У польській фразеології функціонує лексичний варіант цього звороту: nie umieć i psom ogonów zawiazać (Skorupka, 1967, 582), що свідчить про правильність припущення. Натомість в українській фразеології зав'язування хвоста домашньому улюбленцю співвідноситься з майстерністю в роботі (котові (кімиі) [вузлом] хвоста зав'язати „уміти будь-що робити, бути здібним до всього"; Білоноженко et al., 1993, 302), а неспроможність виконання таких дій - з лінощами та неробством (котові хвоста не зав'яже „про лінивого чоловіка"; Мацюк, 2013, 436). Водночас зав'язування (кручення) хвоста свійській тварині в українській фразеології асоціюється з виконанням примітивної, часто брудної, непрестижної роботи: волам (бикам) хвости крутити „виконувати примітивну, часто брудну, непрестижну роботу" (Білоноженко et al., 2003, 317). Амбівалентні конотації фіксуємо в російській діалектній фразеології: в Орловській області така діяльність сприймається як неробство (быкам хвосты крутить „байдикувати”; Мокиенко, Никитина, 2007, 68), тоді як у Волгоградській області співвідноситься з важкою, проте невдячною роботою (быкам хвосты крутить „виконувати важку, невдячну роботу”; Мокиенко, Никитина, 2007, 68).

3 давньою поганською традицією колядування за участі ряджених пов'язані в польській та російській мовах фразеологізми chodzić (biegać) z wilczą skóra po kolędzie „марно витрачати час, байдикувати” (Wysoczański, 2006, 194), водить медведя „байдикувати, лінуватися” (Мокиенко, Никитина, 2008, 393). Украй негативне сприйняття дій, які в межах ритуалу усвідомлюються як сакральні, знаходять своє відображення у значенні пол. дієслова kolędować „пліткувати, гаяти, марнувати час" (Majerowa, Pepłowski, 1976, 674), рос. колядовать „волочитися без діла, без мети”, архангел. коледиться „лінуватися” (Агапкина et al., 1995, 569).

Образ металевого птаха покладено в основу низки негативно конотованих фразеологізмів польської мови: ołowiany ptak, „дармоїд” 
(Krzyżanowski, 1970, 1148), prędki (wartki) jak ołowiany ptaszek (ptak) „про ліниву людину” (Linde, 1858, 715), uwijać sie jak ptaszek ołowiany „абсолютно нічого не робити, байдикувати” (Treder, 2005, 225). Поділяю думку Пасюрківської, що у фразеологізмі ołowiany ptak імпліковано сему 'людина, якій важко рухатися', оскільки родова назва nmax, як символ легкості, протиставляється назві металу - олову, як позначенню ваги, що мотивує значення цього фразеологізму (Пасюрківська, 2009б, 133). В українській народній фразеології олово заміщено залізом: бистрий як залізний птах „про ліниву та малорухливу людину" (Юрченко, Івченко, 1993, 123).

Походження фразеологізму niebieski ptak та його варіантів niebieski ptaszek, ptacy niebiescy „безвідповідальний та легковажний дармоїд, який живе чужим коштом" (Kopaliński, 2003, 829; Krasnowolski, 1907, 271) польські науковці пов'язують з Біблією. В Свангелії від Св. Матвія 6:26 читаємо: „Przypatrzcie się ptakom w powietrzu: nie sieją ani żną i nie zbierają do spichrzów, a Ojciec wasz niebieski je żywi” (Biblia Tysiąclecia, 2006). Варто зазначити, що в українській та російській фразеології вислів укр. синій пmax (рос. синяя птица) має лише позитивні конотації та служить для номінації найзаповітніших мрій, прагнень людини (Мокиенко, Никитина, 2007, 541; Білоноженко et al., 2003, 582-583). Автори „Історико-етимологічного довідника російської фразеології” виводять цей вираз з однойменної п'єси М. Метерлінка, в якій діти шукають синього птаха, що відкриє таємницю речей та щастя. Той, хто знайде синього птаха, буде все знати й бачити (Бирих, Мокиенко, Степанова, 1998, 477).

Курка в польській фразеології має амбівалентні конотації. 3 одного боку, іiї образ використовується для характеристики людини, яка ухиляється від роботи, байдикує: siedzi jak kura na grzędzie (Krzyżanowski, 1972, 181), з другого - для характеристики людини, яка наполегливо працює: gospodarzi jak slepka (де slepka - діалектна назва курки) „наполегливо працює" (Treder, 2005, 202). Натомість в українській народній фразеології курка (квочка) стала прототипом лінивої жінки: $c u$ дить як квочка на яйия „про ліниву жінку” (Юрченко, Івченко, 1993, 66), неповоротка як квочка „про ліниву жінку” (Мацюк, 2013, 438). Аналогічні конотації в носіїв української мови викликає образ зозулі: 
ховається як зозуля (зозулька) по кропиві ,про людину, яка ухиляється від роботи" (Юрченко, Івченко, 1993, 60).

Полювання на окремих видів птахів, зокрема ворон, гав, граків, сорок, снігурів та бугаїв, у фразеології досліджуваних мов співвідноситься 3 розвагами та неробством: пор. пол. kruki łowić (Treder, 2005, 225), strzelać gawrony (wrony, baki) (Treder, 2005, 194, 211; Krzyżanowski, 1969, 40), polować na wrony (Treder, 2005, 211), укр. сорок (граки, гави, ворон) ловити (Шевченко, 2007, 469; Білоноженко et al., 1993, 444); рос. снегирей (гавов) ловить (де рос. гав - від укр. тава „ворона”) (Мокиенко, Никитина, 2007, 110, 626). Очевидно, виникли такі конотації з мисливської практики. Для професійного мисливця полювання на цих птахів - це нераціональна трата пороху та часу, оскільки їх м'ясо має погані смакові якості.

Мураха в польській та українській фразеології має лише позитивні конотації: пор. пол. mrówcza praca „наполеглива, кропітка праця, яка вимагає терпіння та точності” (Müldner-Nieckowski, 2004, 581), mrówcza pracowitość „систематичність і терплячість у роботі” (Müldner-Nieckowski, 2004, 584), pracować jak mrówka „наполегливо, інтенсивно працювати без відпочинку” (Kłosińska, Sobol, Stankiewicz, 2005, 259), pracowity jak mrówka „про дуже працьовиту людину” (Krasnowolski, 1907, 271); укр. роботящий як мурашка „про дуже працьовиту людину" (Юрченко, Івченко, 1993, 97), пращює як мурашка „тяжко, наполегливо працює” (Юрченко, Івченко, 1993, 97), cmapamлива як мурашка „про працьовиту людину” (Доброльожа, 2003, 30). Прикметно, що в Біблії ця комаха виступає символом працьовитості і зразком для наслідування. У Книзі приповістей Соломонових 6:6-6:8 читаємо: „Do mrówki się udaj, leniwcze, patrz na jej drogi - bądź mądry: nie znajdziesz u niej zwierzchnika ni stróża żadnego, ni pana, a w lecie gromadzi swą żywność i zbiera swój pokarm we żniwa" (Biblia Tysiąclecia, 2006). Аналогічні конотації викликає у слов'янської спільноти образ бджоли: пор. пол. pracowity jak pszczółka (pszczoła) „про дуже працьовиту людину" (Krasnowolski, 1907, 271; Krzyżanowski, 1970, 1058); укр. трудитись (праџювати) як [Божа] бджола „дуже напружено, посилено працювати" (Білоноженко et al., 2003, 26), роботяща як бджілка [Майя] „про працьовиту дівчину, жінку” (Юрченко, Івченко, 1993, 14; Мацюк, 2013, 434); рос. трудиться (работать, шуршать) 
как [трудовая] пчела (пчёлка) „наполегливо та невтомно працювати” (Кузнецов, 1998, 1050), жить как пчела „про людину, яка живе в постійній праці" (Мокиенко, Никитина, 2008, 554), трудолюбивый как пчела „про дуже працьовиту людину” (Мокиенко, Никитина, 2008, 554), божья пчёлка „про працьовиту жінку” (Мокиенко, Никитина, $2007,547)$. Незважаючи на те, що трутні $є$ невід'ємною частиною бджолиної сім’і, без якої вона не може розмножуватись, у фразеології корисна діяльність чоловічих особин медоносних бджіл не зафіксована. Зате нездатність збирати корм та непристосованість до виконання будь-яких робіт у вулику, що розцінюється як ледарство, засвідчують фразеологізми: пор. пол. truteń salonowy „про ледачу людину, дармоїда” (Skorupka, 1968, 393), укр. лінивий як трутень „про ліниву людину” (Доброльожа, 2003, 27), до роботи як трутень „про ледачу людину" (Доброльожа, 2003, 26).

Потрапивши у мед чи смолу, муха повільно рухається, оскільки iii крила обтяжує липка і тягуча субстанція. Така поведінка комахи в польській фразеології розцінюється як ледарство та неробство: wlec (poruszać, ruszać) się jak mucha w mazi (miodzie, smole) „повільно діяти, займатися чимось, лінуватися" (Krzyżanowski, 1970, 546; Müldner-Nieckowski, 2004, 417). Мотивуючу роль у фразеологічному порівнянні pracować jak senna mucha „повільно працювати” (Kłosińska, Sobol, Stankiewicz, 2005, 260) виконує прикметник сонний, оскільки крім основного значення „якого хилить до сну, сонливий” означає „позбавлений енергії, тихий, лінивий” (Uniwersalny słownik języka polskiego). Натомість про бездоганно виконану роботу, до якої немає жодних зауважень, поляки кажуть: taki, że mucha nie siada (Uniwersalny słownik języka polskiego). В українській та російській фразеології для позитивної характеристики роботи місце мухи займає комар: пор. рос. комар носу не подточит (Бирих, Мокиенко, Степанова, 1998, 287), укр. [i] комар носа не підточить (Білоноженко et al., 2003, 306). У „Історико-етимологічному довіднику" знаходимо три версії трактування рос. фразеологізму комар носу не подточит. Володимир Миколайович Вакуров трактує образ, що лежить в основі фразеологізму, базуючись на значенні “пошкодити” дієслова подтачивать (Бирих, Мокиенко, Степанова, 1998, 288). Тоді як Дмитро Костянтинович Зєлєнін пояснює фразеологізм, базуючись на діалектному значенні дієслова 
подтачивать „кусати”. „Внутренний смысл - в том, - зазначає автор, - что комар кусает, «подтачивает чей-л. нос»" (Бирих, Мокиенко, Степанова, 1998, 287-288). Валерій Михайлович Мокієнко піддає сумніву останню версію трактування фразеологізму, наводячи його структурно-семантичні варіанти з прийменником под: комар носу не подточит под кого; под добрую сваху и комар носу не подточит. Науковець переконаний, що у фразеологізмі мова йде саме про ніс комара, а дієслово подточить вжито у значенні „просунути, пропхнути, проштовхнути” (Бирих, Мокиенко, Степанова, 1998, 288).

Негативні асоціації викликає образ воші в носіїв польської та української мов. Образ кровоссального паразита використовується в діалектній фразеології для характеристики людини, яка не любить працювати: пор. пол. leniwy jak wesz (Wysoczański, 2006, 188), укр. лінивий (ледачий) як вош (Доброльожа, 2003, 27). Натомість у російській фразеології образ воші позитивно конотований і використовується для характеристики людини, яка почала виконувати роботу з великим завзяттям, дуже старанно: приняться за дело как вошь за тело (Мокиенко, Никитина, 2008, 121).

Досліджуючи мотивацію зоофразеологізмів в українській мові, Селіванова звертає увагу на те, що декодування деяких зворотів може бути ускладнене омонімією назв тварин (Селіванова, 2004, 165). У польській науковій літературі існує кілька коментарів щодо мотивації фразеологізму zbijać bąki „марно витрачати час, байдикувати" (Müldner-Nieckowski, 2004, 63). Єжи Тредер та Юліан Кшижановський пов'язують фразеологізм zbijać baki $з$ мисливською практикою ходити на бугая (Treder, 2005, 191; Krzyżanowski, 1960, 20). Кшижановський (Krzyżanowski, 1960, 20) мотивує значення цього фразеологізму непридатністю до вживання ані м'яса, ані пір'я птаха. Леон Заремба пов'язує цей вислів з безглуздим заняттям - ловити комах. Посилаючись на Словник польської мови за редакцією Вітольда Дорошевського та Словник польської мови Мєчислава Шимчака, науковець визнає ентомологічне значення слова bak у складі фразеологізму zbijać bąi та відкидає його орнітологічне значення „птах з родини чаплевих (Bataurus stellaris)" (Zaręba, 2004, 17). Найвірогідніший, на мою думку, інший варіант мотивації, який мені підказав Словник польських діалектів. 
Автори словника виводять цей зворот з розваги сільської молоді збивати насіння з цибулі, оскільки $b a c k$ у діалектах означає „насінна коробочка у вигляді суцвіття" (Reichan, 1986, 3). Підтверджує цю теорію початкова форма звороту zbijać baki z cebuli (Reichan, 1986, 6). Відтак, пропоную такий мотиваційний ланцюжок, у який можна вкласти значення фразеологізму zbijać baki: „збивати цибулю” $\rightarrow$ „завдавати шкоди” $\rightarrow$ „марнувати час” $\rightarrow$ „ледарювати”. Рос. фразеологізм гонять собак „байдикувати”, на думку Мокієнка, походить із термінології гри, оскільки собака позначає в північноросійському діалекті палку (рос. діал. сучка), якою ганяють кулю у грі. До термінології гри ця палка потрапила із тваринного світу (пор. свинка, чиж, козелок - назви у грі в бабки). „Перейдя из профессионального языка бабочников в общенародный язык, - зазначає автор, - слово собака утратило свое «игровое» значение" (Бирих, Мокиенко, Степанова, 1998, 536). Щоправда, наявність в українській мові низки лексичних варіантів фразеологізму ганяти собак „байдикувати” (дражнити собак, ганяти бліх, лякати бліх) викликає сумніви щодо подібної етимології в Селіванової $(2004,166)$. Перелік лексичних варіантів значно розширює діалектна фразеологія досліджуваних мов: пор. пол. gonić muchy, gonić motyle (Krzyżanowski, 1970, 527, 548), lelecha gonić (Krzyżanowski, 1970, 288), укр. вовків ганяти, ганяти ворон, ганяти голубів, ганяти горобців, ганяти крис, ганяти мух, ганяти козла (Ужченко, 2013, 68, 90, 95; Шевченко, 2007, 468); рос. гонять голубей, гонять блох, гонять лосей, гонять лягушек, гонять слона (слонов) (Мокиенко, Никитина, 2007, 149, 43, 371, 377 , 622), дразнить собак (Мокиенко, Никитина, 2007, 627).

Отже, для відображення позитивного ставлення до роботи у фразеологізмах залучено образи комах та свійських тварин: бджілки (усі досліджувані мови), коня (усі досліджувані мови), віслюка (українська мова), бика (російська мова), мурашки (польська та українська мови), воші (російська мова). Лінь та неробство у фразеології уособлюють образи комах, домашніх улюбленців, свійських тварин та птахів: кота (усі досліджувані мови), віслюка (російська мова), собаки (українська мова), птаха (польська та українська мови), курки (українська мова), трутня (українська та російська мови), воші (польська та українська мови). Амбівалентні асоціації у фразеології мають образи свійських 
та домашніх тварин: вола (усі досліджувані мови), собаки (польська та російська мови), курки (польська мова), віслюка (польська мова).

У фразеології фіксуємо як дійсно існуючі риси, що відповідають реальній поведінці тварин, так і приписувані їм, на основі стереотипного уявлення людей про тварин, риси. До зооморфних властивостей тварин відносимо: нездатність трутнів збирати корм та їхню непристосованість до виконання будь-яких робіт у вулику; особливість зозулі не висиджувати потомство, а підкидати свої яйця у гнізда інших пташок; погані смакові якості м'яса ворони, кажана та бугая. До незооморфних властивостей зараховуємо судження про те, що осел - це вперта та лінива тварина.

3'ясовано, що здебільшого семантика фразеологізмів із зоокомпонентами пов'язана зі способом життя тварин, яким його сприймають люди, меншою мірою - сюжетами байок, поганськими традиціями, кулінарною й мисливською практикою. Трапляються випадки, коли декодування фразеологізмів ускладнюється омонімією назв тварин.

\section{Лiтература}

Агапкина, T. A. et al. (1995). Славянские древности: Этнолингвистический словарь, т. II: Д-К (Крошки). Москва: Международные отношения.

Бирих, А. К., Мокиенко В. М., Степанова Л. И. (1998). Словарь русской фразеологии. Историко-этимологический справочник. Санкт-Петербург: Фолио-Пресс.

Бирюкова, Н. В. (1990). Анималистическая фразеология русского языка. [Автореферат дисертації на здобуття наукового ступеня кандидата філологічних наук]. Ташкент: Ташкентский государственный университет.

Білоноженко, В. M. et al. (1993). Фразеологічний словник украйнської мови, кн. I. Київ: Наукова думка.

Білоноженко, В. М. et al. (2003). Словник фразеологізмів украӥнської мови. Київ: Наукова думка.

Гребенюк, А. В. (2014). Фразеологізми украӥнської мови з зоосемічним компонентом як виразники аксіологічних характеристик. [Автореферат дисертації на здобуття наукового ступеня кандидата філологічних наук]. Запоріжжя: Запорізький національний університет.

Доброльожа, Г. М. (2003). Красне слово - як золотий ключ: Постійні народні порівняння в говірках Середнього Полясся та суміжних територій. Житомир: Волинь. 
Доброльожа, Г. М. (2005). Місие кота на українській фразеологічній печі. „Мова і культура" вип. 8, т. 5, ч. 1, с. 237-242.

Доброльожа, Г. М. (2004). Образна парадигма фразеологізмів з компонентом "собака”. „Вісник Житомирського державного університету ім. І. Франка” № 14, c. $223-227$.

Доброльожа, Г. М. (2010). Фразеологічний словник говірок Житомирщини. Житомир: ПП Туловський.

Жайворонок, В. В. (2018). Антологія знаків української етнокультури: Словник-довідник. Київ: Наукова думка.

Кононенко, I. (2012). Украӥнська та польська мови: контрастивне дослідження. Warszawa: Wydawnictwa Uniwersytetu Warszawskiego.

Кузнецов, С. А. (1998). Большой толковый словарь русского языка. Санкт-Петербург: Норинт.

Мацюк, 3. (2013). Що сільце, то нове слівие: слов. фразеологізмів Західного Полісся. Луцьк: Вежа-Друк.

Мирошніченко, I. М. (2011). Працьовитість і ледарство у фразеологізмах із компонентами-орнітонімами та -ентомонімами (на матеріалі польської та української мов). В: Життя у слові: збірник наукових праџь на пошану академіка В. М. Русанівського. Відп. ред. В. Г. Скляренко. Київ: Видавничий дім Дмитра Бураго, с. 210-216.

Мирошніченко, І. М. (2014). Фразеосемантичне поле „пращьовитість / неробство" в польській мові. Київ: Наукова думка.

Мокиенко, В. М., Никитина, Т. Г. (2007). Больщой словарь русских поговорок. Москва: ЗАО „ОЛПА Медиа Групп”.

Мокиенко, В. М., Никитина, Т. Г. (2008). Большой словарь русских народных сравнений. Москва: ЗАО „ОЛМА Медиа Групп”.

Олексієнко, Н. О. (2008). Фразеологізми з компонентами кіт, кішка у східнослобожанських та східностепових говірках (ідеографічний аспект). „Лінгвістика" № 2 (14), с. 126-131.

Пасюрківська, М. В. (2009а). Зоонімічна лексика в польській фразеології: склад, семантика, функиії. [Автореферат дисертації на здобуття наукового ступеня кандидата філологічних наук]. Київ: Київський національний університет ім. Тараса Шевченка.

Пасюрківська, М. В. (2009б). Зоонімічна лексика в польській фразеології: склад, семантика, функціï. [Рукопис дисертації на здобуття наукового ступеня кандидата філологічних наук]. Київ: Київський національний університет ім. Тараса Шевченка.

Сагата, Ю. І. (2013). Динамічні прочеси в сучасній польській фразеології з анімалістичним компонентом. [Автореферат дисертації на здобуття наукового ступеня кандидата філологічних наук]. Київ: Інститут мовознавства ім. О. О. Потебні НАН України.

Сагата, Ю. (2008). Кіт у польській та украӥнській фразеології. „Проблеми слов'янознавства" вип. 57, с. 282-290. 
Селіванова, О. О. (2004). Нариси з украӥнської фразеології (психокогнітивний та етнокультурний аспекти). Київ-Черкаси: Брама.

Ужченко, Д. В. (2000). Семантика украӥнських зоофразеологізмів в етнокультурному висвітленні: [Автореферат дисертації на здобуття наукового ступеня кандидата філологічних наук]. Харків: Харківський державний педагогічний університет ім. Г. С. Сковороди.

Ужченко, В. Д., Ужченко, Д. В. (2013). Фразеологічний словник східнослобожанських i степових говірок Донбасу. Луганськ: Вид-во ДЗ „ЛНУ імені Тараса Шевченка”.

Шевченко, Н. (2007). Внутрішній світ людини в зоофразеологізмах (на матеріалі східнослобожанських і східностепових говірок Донбасу). „Вісник Прикарпатського нац. ун-ту ім. Василя Стефаника" вип. XV-XVIII, с. 637-640.

Юрченко, О. С., Івченко, А. О. (1993). Словник стійких народних порівнянь. Харків: Основа.

[Agapkina, T. A. et al. (1995). Slavyanskie drevnosti: Etnolingvisticheskiy slovar, t. II: D-K (Kroshki). Moskva: Mezhdunarodnyie otnosheniya.

Birih, A. K., Mokienko V. M., Stepanova L. I. (1998). Slovar' russkoy frazeologii. Istoriko-etimologicheskiy spravochnik. Sankt-Peterburg: Folio-Press.

Biryukova, N. V. (1990). Animalisticheskaya frazeologiya russkogo yazyka. [Avtoreferat dissertatsii na soiskanie nauchnoy stupeni kandidata filologicheskih nauk]. Tashkent: Tashkentskiy gosudarstvennyiy universitet.

Bilonozhenko, V. M. et al. (1993). Frazeolohichnyi slovnyk ukrainskoi movy, kn. 1. Kyiv: Naukova dumka.

Bilonozhenko, V. M. et al. (2003). Slovnyk frazeolohizmiv ukrainskoi movy. Kyiv: Naukova dumka.

Hrebeniuk, A. V. (2014). Frazeolohizmy ukrain'skoi movy z zoosemichnym komponentom yak vyraznyky aksiolohichnykh kharakterystyk. [Avtoreferat dissertatsii na soiskanie nauchnoy stupeni kandidata filologicheskih nauk]. Zaporizhzhia: Zaporizkyi natsional'nyi universytet.

Dobrolozha, H. M. (2003). Krasne slovo - yak zolotyi kliuch: Postiini narodni porivniannia $v$ hovirkakh Seredn'oho Poliassia ta sumizhnykh terytorii. Zhytomyr: Volyn.

Dobrolozha, H. M. (2005). Mistse kota na ukrainskii frazeolohichnii pechi. „Mova i kul'tura" vyp. 8, t. 5, ch. 1, s. 237-242.

Dobrolozha, H. M. (2004). Obrazna paradyhma frazeolohizmiv z komponentom "sobaka”. „Visnyk Zhytomyrs'koho derzhavnoho universytetu im. I. Franka” № 14, s. 223-227.

Dobrolozha, H. M. (2010). Frazeolohichnyi slovnyk hovirok Zhytomyrshchyny. Zhytomyr: PP Tulovskyi.

Zhaivoronok, V. V. (2018). Antolohiia znakiv ukrain'skoi etnokultury: Slovnyk-dovidnyk. Kyiv: Naukova dumka.

Kononenko, I. (2012). Ukrain'ska ta pol'ska movy: kontrastyvne doslidzhennia. Warszawa: Wydawnictwa Uniwersytetu Warszawskiego.

Kuznetsov, S. A. (1998). Bol'shoy tolkovyiy slovar' russkogo yazyika. Sankt-Peterburg: Norint. 
Matsiuk, Z. (2013). Shcho sil'tse, to nove slivtse: slov. frazeolohizmiv Zakhidnoho Polissia. Luts'k: Vezha-Druk.

Myroshnichenko, I. M. (2011). Pratsovytist' i ledarstvo u frazeolohizmakh iz komponentamy-ornitonimamy ta -entomonimamy (na materiali pol'skoi ta ukrains'koi mov). V: Zhyttia u slovi: zbirnyk naukovykh prats' na poshanu akademika V. M. Rusanivs 'koho. Vidp. red. V. G. Sklyarenko, Kyiv: Vydavnychyi dim Dmytra Buraho, s. 210-216.

Myroshnichenko, I. M. (2014). Frazeosemantychne pole „pratsovytist' / nerobstvo” v polskii movi. Kyiv: Naukova dumka.

Mokienko, V. M., Nikitina, T. G. (2007). Bol'shoy slovar' russkih pogovorok. Moskva: ZAO „OLPA Media Grupp”.

Mokienko, V. M., Nikitina, T. G. (2008). Bol'shoy slovar' russkih narodnyih sravneniy. Moskva: ZAO „OLMA Media Grupp”.

Oleksiienko, N. O. (2008). Frazeolohizmy z komponentamy kit, kishka u skhidnoslobozhans'kykh ta skhidnostepovykh hovirkakh (ideohrafichnyi aspekt). „Linhvistyka” № 2 (14), s. 126-131.

Pasiurkivs'ka, M. V. (2009a). Zoonimichna leksyka v pol'skii frazeolohii: sklad, semantyka, funktsii. [Avtoreferat dissertatsii na soiskanie nauchnoy stupeni kandidata filologicheskih nauk]. Kyiv: Kyivs'kyi natsional'nyi universytet im. Tarasa Shevchenka.

Pasiurkivs'ka, M. V. (2009b). Zoonimichna leksyka v pol'skii frazeolohii: sklad, semantyka, funktsii. [Rukopys dysertatsii na zdobuttia naukovoho stupenia kandydata filolohichnykh nauk]. Kyiv: Kyivs'kyi natsional'nyi universytet im. Tarasa Shevchenka.

Sahata, Yu. I. (2013) Dynamichni protsesy v suchasnii pol's 'kii frazeolohii z animalistychnym komponentom: [Avtoreferat dissertatsii na soiskanie nauchnoy stupeni kandidata filologicheskih nauk]. Kyiv: Instytut movoznavstva im. O. O. Potebni NAN Ukrainy.

Sahata, Yu. (2008). Kit u pol's 'kii ta ukrains 'kii frazeolohii. „Problemy slovianoznavstva" vyp. 57, s. 282-290.

Selivanova, O. O. (2004). Narysy z ukrains'koi frazeolohii (psykhokohnityvnyi ta etnokul'turnyi aspekty). Kyiv-Cherkasy: Brama.

Uzhchenko, D. V. (2000). Semantyka ukrains'kykh zoofrazeolohizmiv v etnokulturnomu vysvitlenni: [Avtoreferat dissertatsii na soiskanie nauchnoy stupeni kandidata filologicheskih nauk]. Kharkiv: Kharkivs'kyi derzhavnyi pedahohichnyi universytet im. H. S. Skovorody.

Uzhchenko, V. D., Uzhchenko, D. V. (2013). Frazeolohichnyi slovnyk skhidnoslobozhans'kykh i stepovykh hovirok Donbasu. Luhans'k: Vyd-vo DZ "LNU imeni Tarasa Shevchenka".

Shevchenko, N. (2007). Vnutrishnii svit liudyny $v$ zoofrazeolohizmakh (na materiali skhidnoslobozhans'kykh i skhidnostepovykh hovirok Donbasu). „Visnyk Prykarpats'koho nats. un-tu im. Vasylia Stefanyka” vyp. XV-XVIII, s. 637-640.

Yurchenko, O. S., Ivchenko, A. O. (1993). Slovnyk stiikykh narodnykh porivnian'. Kharkiv: Osnova]. 
Adalberg, S. (1894). Księga przystów, przypowieści i wyrażeń przystowiowych polskich. Warszawa: Druk Emila Skiwskiego.

Anusiewicz, J. (1990). Językowo-kulturowy obraz kota w polszczyźnie. Antropocentryzm frazeologii potocznej. „Etnolingwistyka” № 3, s. 96-141.

Biblia Tysiąclecia. (2006). Pismo Święte Starego i Nowego Testamentu. Poznań: Pallottinum. https://biblia.deon.pl/rozdzial.php?id=249\&slowa=Przypatrzcie $\% 20$ si $\%$ EA\%20ptakom. 26.02.2021.

Doroszewski, W. (1958). Stownik języka polskiego, t. I: $A-C ́$. Warszwa: PAN.

Karolak, S. (1998). Stownik frazeologiczny rosyjsko-polski, t. II: П-Я. Warszawa: Energeia.

Kłosińska, A., Sobol, E., Stankiewicz, A. (2005). Wielki słownik frazeologiczny PWN z przystowiami. Warszawa: Wydawnictwo Naukowe PWN.

Kopaliński, W. (2003). Stownik mitów i tradycji kultury. Warszawa: RYTM.

Krasnowolski, A. (1907). Stowniczek frazeologiczny. Poradnik dla piszacych. Warszawa: Książki dla wszystkich.

Krzyżanowski, J. (1960). Mądrej głowie dość dwie słowie, t. 2. Warszawa: PIW.

Krzyżanowski, J. (1969). Nowa księga przystów i wyrażeń przystowiowych polskich, t. I. Warszawa: PIW.

Krzyżanowski, J. (1970). Nowa księga przystów i wyrażeń przystowiowych polskich, t. II. Warszawa: PIW.

Krzyżanowski, J. (1972). Nowa księga przystów i wyrażeń przysłowiowych polskich, t. III. Warszawa: PIW.

Linde, S. B. (1858). Słownik języka polskiego, t. IV: P. Lwów: Drukarnia Zakładu Ossolińskich.

Majerowa, M., Pepłowski, F. (1976). Słownik polszczyzny XVI wieku, t. X: K-Korzyść. Wrocław-Warszawa-Kraków-Gdańsk: PAN.

Mosiołek-Kłosińska, K. (1995). Motywacja związków frazeologicznych zawierających wyrazy pies $i$ kot. „Etnolingwistyka” № 7, s. 21-31.

Müldner-Nieckowski, P. (2004). Wielki stownik frazeologiczny języka polskiego: wyrażenia, zwroty, frazy. Warszawa: Świat Książki.

Rak, M. (2007a). Językowo-kulturowy obraz człowieka na podstawie animalistycznej frazeologii gwar Orawy, Podhala i Spisza, t. V: Frazeologia a językowy obraz świata przełomu wieków. Red. W. Chlebda. Opole: Wydawnictwo Uniwersytetu Opolskiego, s. 111-117.

Rak, M. (2007b). Językowo-kulturowy obraz zwierząt utrwalony w animalistycznej frazeologii gwar Gór Świętokrzyskich i Podtatrza (na tle porównawczym). Kraków: Wydawnictwo „Scriptum”.

Reichan, J. (1986). Stownik gwary polskiej. Wrocław-Warszawa-Kraków-GdańskŁódź: PAN.

Reichan, J., Urbańczyk S. (1991). Stownik gwar polskich. Wrocław-Warszawa-Kraków-Gdańsk-Lódź: PAN.

Skorupka, S. (1967). Słownik frazeologiczny języka polskiego, t. I. Warszawa: Wiedza Powszechna. 
Skorupka, S. (1968). Słownik frazeologiczny języka polskiego, t. II. Warszawa: Wiedza Powszechna.

Treder, J. (2005). Nazwy ptaków we frazeologii i inne studia $z$ frazeologii i paremiologii polskiej. Gdańsk: Uniwersytet Gdański.

Wysoczański, W. (2006). Językowy obraz świata w porównaniach zleksykalizowanych (na materiale wybranych języków). Wrocław: Uniwersytet Wrocławski.

Zaręba, L. (2004). Szkice z frazeologii porównawczej francusko-polskiej i polsko-francuskiej. Kraków: Księgarnia Akademicka. 